\title{
Effects of a small natural barrier on the spatial distribution of the fish assemblage in the Verde River, Upper Paraná River Basin, Brazil
}

\author{
J. C. Silva $a^{a}$ É. A. Gubiania, ${ }^{a, b}$, P. A. Piana ${ }^{a, b}$ and R. L. Delariva ${ }^{a, c}$ \\ aPrograma de Pós-graduação em Conservação e Manejo de Recursos Naturais, Universidade Estadual do Oeste do Paraná \\ - UNIOESTE, Rua Universitária, 2069, Jardim Universitário, CEP 85819-110, Cascavel, PR, Brazil \\ bPrograma de Pós-graduação em Recursos Pesqueiros e Engenharia de Pesca, Grupo de Pesquisas em Recursos Pesqueiros \\ e Limnologia, Instituto Neotropical de Pesquisas Ambientais, Universidade Estadual do Oeste do Paraná - UNIOESTE, \\ Rua da Faculdade, 645, Jardim La Salle, CEP 85903-000, Toledo, PR, Brazil \\ ${ }^{\circ}$ Centro de Ciências Biológicas e da Saúde, Universidade Estadual do Oeste do Paraná - UNIOESTE, Rua Universitária, \\ 2069, Jardim Universitário, CEP 85819-110, Cascavel, PR, Brazil \\ *e-mail: egubiani@yahoo.com.br
}

Received: January 16, 2015 - Accepted: July 22, 2015 - Distributed: November 30, 2016

(With 3 figures)

\begin{abstract}
Geographical barriers influence species distribution and play an important role in the segregation of fish assemblages. The present study aims to test the influence of a small natural barrier on the spatial distribution of fish species in the Verde River, Upper Paraná River Basin, Brazil, considering two biotopes: upstream and downstream of the Branca Waterfall. We observed the highest species richness downstream of the Branca Waterfall, which also had the highest number of exclusive species. Richness, evenness, and abundance varied significantly among biotopes. The composition and structure of the fish assemblage differed between biotopes, which were characterized by different indicator species, mainly downstream of the Branca Waterfall. Physical and chemical variables and geographical distance between sites were not responsible for the differences observed. Hence, the present study shows that small barriers can also be crucial in structuring fish fauna and play a key role in the segregation of fish assemblages.
\end{abstract}

Keywords: community ecology, fish fauna, segregation, spatial distribution, waterfalls.

\section{Efeitos de uma pequena barreira natural sobre a distribuição espacial da assembleia de peixes no rio Verde, bacia do alto rio Paraná, Brasil}

\section{Resumo}

As barreiras geográficas influenciam a distribuição das espécies e desempenham um papel importante na segregação das assembleias de peixes. Dessa forma, o objetivo deste estudo foi avaliar mudanças espaciais na assembleia de peixes do rio Verde, sob a influência de uma pequena barreira geográfica natural, bacia do alto rio Paraná, Mato Grosso do Sul, Brasil. Para isso, seis locais foram amostrados e agrupados em dois biótopos: montante e jusante da cachoeira Branca. Maior riqueza e número de espécies exclusivas foram observadas a jusante da cachoeira Branca. A riqueza, equitabilidade e abundância diferiram significativamente entre os biótopos. Além disso, a composição e a estrutura da assembleia de peixes também diferiram entre os biótopos, os quais foram caracterizados por distintas espécies indicadoras, especialmente a jusante da cachoeira Branca. As variáveis físicas e químicas da água e as distâncias geográficas, entre os locais, não foram responsáveis pelas diferenças observadas. Dessa forma, este estudo demonstrou que pequenas barreiras geográficas podem ser cruciais na estruturação da ictiofauna e desempenhar um papel-chave na segregação de assembleias de peixes.

Palavras-chave: ecologia de comunidades, ictiofauna, segregação, distribuição espacial, corredeiras.

\section{Introduction}

Understanding species distribution is one of the main challenges in ecology. In most situations, species have their distribution determined by a series of historical and environmental factors. The knowledge of how these factors affect species distribution is important to build predictive models (Jackson et al., 2001; Teixeira et al., 2005; Súarez and Petrere Junior, 2007) and to understand spatial and temporal organization patterns of fish assemblages. Fish assemblages are expected to change along stretches of the same river, as a result of evolutionary processes and adaptations of each species. These processes and adaptations are modulated by habitat heterogeneity, environmental 
influences, and human activities (e.g., removal of riparian vegetation, construction of dams, canalization, and pollution; Meador and Goldstein, 2003).

Several factors that operate at different spatial and temporal scales determine which species can colonize and persist in specific habitats (Hoeinghaus et al., 2007; Rahel, 2007). Hence, regional characteristics may influence the composition and diversity of local fish assemblages (Angermeier and Winston, 1998). These characteristics act as a series of ecological screens or filters (Jackson and Harvey, 1989; Poff, 1997; Quist et al., 2005; Hugueny et al., 2010), such as food resource availability (Uieda and Pinto, 2011), habitat complexity (Alexandre and Almeida, 2010; Felipe and Súarez, 2010), and natural barriers (Robinson and Rand, 2005; Torrente-Vilara et al., 2011; Dias et al., 2013). Cascades, rapids, and waterfalls are potential geographical barriers for the dispersion of aquatic organisms, through the decrease of habitat connectivity; thus, they are crucial in determining species distribution (Rahel, 2007).

Differences in freshwater assemblages among sites may be determined by connectivity (Miranda and Raborn, 2000; Rahel, 2007; Cote et al., 2009) or isolation of the aquatic systems (Torrente-Vilara et al., 2011). Connectivity is one of the main forces that shapes fish population dynamics and leads to changes in the community (Olden et al., 2001; Petry et al., 2003). According to the serial discontinuity concept of lotic ecosystems (Ward and Stanford, 1983; Stanford and Ward, 2001), artificial barriers disrupt the longitudinal gradient of the river. Artificial barriers alter the river biotic and abiotic conditions and lead to variations in the composition and structure of the fish assemblage between upstream and downstream stretches. Likewise, natural barriers may cause faunal discontinuities and increase dissimilarities in the ichthyofauna, as changes in landscape characteristics cause habitat alterations and increase species turnover along the longitudinal gradient (Balon and Stewart, 1983; Rahel and Hubert, 1991)

This study aims at accessing the spatial distribution of fish species in two biotopes: upstream and downstream of the Branca Waterfall, Verde River, Upper Paraná River Basin, Brazil. We assessed the effect of a small natural barrier on the spatial distribution of fish. We expected most of the differences between fish assemblages to be better explained by the small natural barrier than by local environmental conditions. Therefore, we aimed at answering the following questions: (i) Are fish assemblage structure and composition different upstream and downstream of the waterfall?; (ii) Are those differences in composition and structure related to the presence of a small natural barrier?; (iii) Do the composition and structure of fish assemblages in the area influenced by physical and chemical variables of the water?

\section{Material and Methods}

\subsection{Study area}

The Verde River Water Basin is located in the Brazilian Cerrado, the second largest biome in the country and one of the world's biodiversity hotspots (Klink and Machado, 2005; Abell et al., 2008). It comprises the northeastern part of the state of Mato Grosso do Sul, with the municipalities of Camapuã, Costa Rica, Água Clara, Ribas do Rio Pardo, Brasilândia, and Três Lagoas. Its mouth is located in the Paraná River, in the reservoir of the Engenheiro Sérgio Motta Hydropower Plant (locally known as Porto Primavera Dam), state of São Paulo.

The Branca Waterfall is located in the middle stretch of the Verde River close to Água Clara. It is a small obstacle, with approximately $1.5 \mathrm{~m}$ in height, characterized by a gradient of intense flow, with several cascades, turbulent waters, and extensive rapids. In this stretch, the substrate is rocky and the waterfall surroundings are composed of marginal native shrubby vegetation and rocks.

\subsection{Sampling}

We sampled fish species in six sites along the Verde River (Figure 1). In the spatial variation analysis, aiming at identifying the effects of the natural barrier on fish dispersal, we grouped the sites into two biotopes: upstream (1-3; Figure 1) and downstream of the Branca Waterfall (4-6; Figure 1). The physical characteristics of each biotope are described in Table 1.

Sampling was carried out monthly during the fish reproductive season (from November 2010 to March 2011 and from October 2011 to February 2012) and quarterly from May to August 2011, summing up 12 samples. We used as fishing devices gillnets (mesh sizes of 2.4, 3, 4, 5, 6, 7, 8, 9, $10,12,14$, and $16 \mathrm{~cm}$ between opposite knots) and trammel nets (with inner mesh sizes of 6,7 and $8 \mathrm{~cm}$ between opposite knots), locally known as feiticeiras, with $1.5 \mathrm{~m}$ in height and $20 \mathrm{~m}$ in length. We let nets set for $24 \mathrm{~h}$ and checked them at every $8 \mathrm{~h}$. After capturing fish specimens, we anesthetized them with a benzocaine solution $(250 \mathrm{mg} / \mathrm{l})$ following AVMA (2001), fixed them in plastic bags containing formaldehyde $10 \%$ and placed them in polyethylene containers. In the laboratory, we identified the fish following Graça and Pavanelli (2007), measured (total and standard length in $\mathrm{cm}$ ), and weighed them $(\mathrm{g})$. We preserved vouchers of each species in alcohol $70 \%$ and deposited them in the fish collection of Nupélia (Núcleo de Pesquisas em Limnologia, Ictiologia e Aquicultura) at Universidade Estadual de Maringá (available at http://peixe.nupelia.uem.br)

\subsection{Environmental variables}

Concomitantly with fish sampling, we measured water physical and chemical variables, such as temperature $\left({ }^{\circ} \mathrm{C}\right.$; mercury bulb thermometer), electrical conductivity $(\mu \mathrm{S} / \mathrm{cm}$; portable conductivity meter Digimed ${ }^{\circledR}$ DM-3P; Digimed Analytical Instrumentation - Santo Amaro, São Paulo State, Brazil), dissolved oxygen (mg/L; portable oxymeter YSI $550 \mathrm{~A}$ ), $\mathrm{pH}$ (portable phmeter Digimed ${ }^{\circledR}$ DM-2P), turbidity (NTU, Turbidimeter LaMotte ${ }^{\circledR} 2020 \mathrm{e}$ ), and transparency (Secchi disk), to describe the environmental conditions.

\subsection{Data analysis}

\subsubsection{Assemblage attributes}

We estimated species abundance based on catch per unit effort (CPUE) in terms of number of individuals (individuals $/ 1,000 \mathrm{~m}^{2}$ of net/day) and biomass $\left(\mathrm{kg} / 1,000 \mathrm{~m}^{2}\right.$ of net/day), following King (1995). 


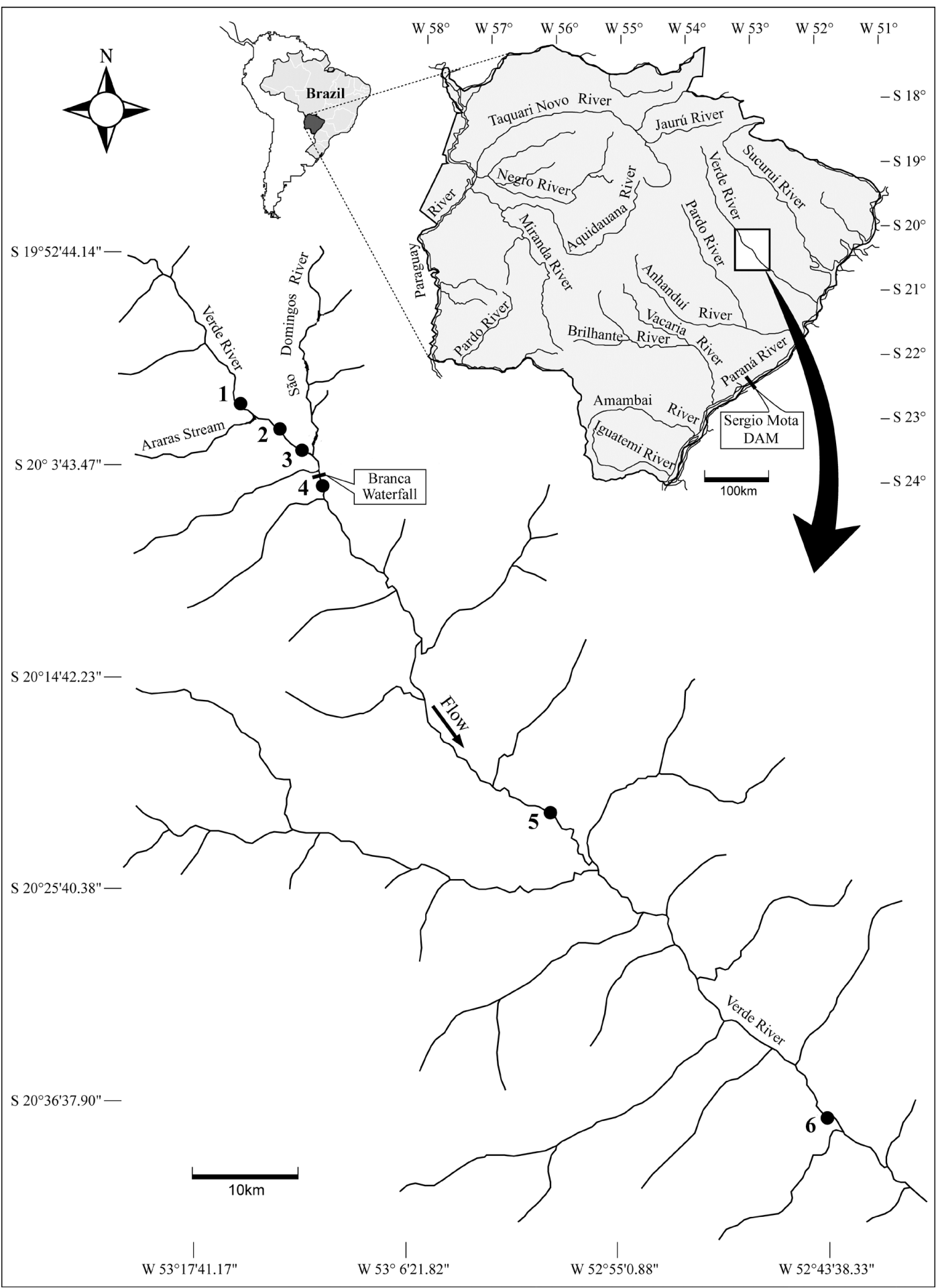

Figure 1. Spatial location of sampling sites in the Verde River, Upper Paraná River Basin, state of Mato Grosso do Sul, Brazil. Sampling sites were grouped according two biotopes: upstream (1-3) and downstream (4-6) of the Branca Waterfall.

For each month and site (per sample), we calculated species richness (number of fish species), Shannon diversity index $\left(H^{\prime}=-\sum_{\mathrm{i}=1}^{\mathrm{s}} p i \mathrm{x} \ln (p i)\right.$, where: $\mathrm{s}=$ number of species and $p i=$ proportion of species $i$ ), and evenness
$\left(\mathrm{E}=H^{\prime} / \mathrm{lnS}\right.$, where: $H^{\prime}=$ Shannon diversity index and $\mathrm{S}=$ species richness) (Magurran, 1988).

We used a t-test for independent samples to evaluate spatial differences between biotopes relative to species 
Table 1. Physical characteristics of the sampling sites in the Verde River, Upper Paraná River Basin, state of Mato Grosso do Sul, mid-western Brazil.

\begin{tabular}{|c|c|c|c|c|c|}
\hline Site & Biotope & $\begin{array}{c}\text { Predominant } \\
\text { substrate } \\
\end{array}$ & $\begin{array}{c}\text { Riparian } \\
\text { vegetation }\end{array}$ & $\begin{array}{c}\text { Channel } \\
\text { physiography }\end{array}$ & Surrounding \\
\hline 1,2 and 3 & $\begin{array}{l}\text { Upstream of the } \\
\text { Branca Waterfall }\end{array}$ & Rocky/sandy & $\begin{array}{l}\text { Preserved region } \\
\text { with native } \\
\text { riparian vegetation } \\
\text { (shrubby) with } 20 \\
\text { to } 30 \mathrm{~m} \text { in width } \\
\text { on both margins. }\end{array}$ & $\begin{array}{l}\text { Width between } 40 \\
\text { and } 150 \mathrm{~m} \text {, with } \\
\text { fast and turbulent } \\
\text { waters, few } \\
\text { backwater, and } \\
\text { shelter sites. Some } \\
\text { marginal lagoons } \\
\text { and floodplain } \\
\text { areas. }\end{array}$ & $\begin{array}{l}\text { Extensive } \\
\text { livestock farming } \\
\text { and eucalyptus } \\
\text { plantation. }\end{array}$ \\
\hline 4,5 and 6 & $\begin{array}{l}\text { Downstream of the } \\
\text { Branca Waterfall }\end{array}$ & Rocky/sandy & $\begin{array}{l}\text { Native riparian } \\
\text { vegetation } \\
\text { (shrubby) with } \\
10 \mathrm{~m} \text { in width, on } \\
\text { average. }\end{array}$ & $\begin{array}{l}\text { Width between } \\
40 \text { and } 60 \mathrm{~m} \text {, with } \\
\text { fast and turbulent } \\
\text { waters, backwater } \\
\text { areas, shelters on } \\
\text { the margins, and } \\
\text { large floodplain } \\
\text { regions. }\end{array}$ & $\begin{array}{l}\text { Extensive } \\
\text { livestock farming } \\
\text { and reforestation. }\end{array}$ \\
\hline
\end{tabular}

richness, Shannon diversity index, evenness, CPUE (number and biomass), and environmental variables.

\subsubsection{Fish assemblage distribution patterns}

To summarize composition and structure of the fish assemblage, we applied a nonmetric multidimensional scaling (NMDS; Kruskal, 1964). We computed Bray-Curtis distances and we followed the general NMDS procedure outlined by McCune and Grace (2002). We used random starting configurations, the number of runs with the real data was 100 , and the stability criterion was standard deviations $\leq 0.005$ in stress over 100 iterations. This analysis was performed using the CPUE data matrix in number (square root transformed to remove the effect of high values) in different months and sampling sites (by sample).

We assessed the variation in assemblage composition and structure in relation to position of sites relative to Branca Waterfall (biotopes; "a" component), geographic distances between sites ("b" component), and environmental variables ("c" component) using variation partitioning routine (Varpart; Peres-Neto et al., 2006). We chose the Varpart routine because it divides the variation of a response matrix into two, three, or four explanatory matrices and assesses the individual contributions of each one, and its interactions. We used Hellinger transformation (Legendre and Gallagher, 2001) on CPUE data (in number of each species) of assemblage structure to preserve Euclidian metric distances. The matrix of geographic distances was composed of site coordinates in UTM and was included in the analysis because close sites probably have more similar assemblages than distant ones (Tobler, 1970; Nekola and White, 1999). So, varpart partitioning out this variation to test the effects of other matrices. We applied significance tests for each contribution matrix with redundancy analysis (RDA function), followed by an analysis of variance (ANOVA with 999 permutations), as suggested by Oksanen et al. (2015).

We used the indicator value analysis (IndVal; Dufrêne and Legendre, 1997) to detect how strongly each species contributed to the differences between biotopes. To test the significance of the indicator value we used a Monte Carlo procedure with 1,000 permutations.

Assemblage attributes (species richness, Shannon diversity index, and evenness), NMDS, and IndVal were all calculated in the software PC-Ord ${ }^{\circledR} 5.0$ (McCune and Mefford, 2006). The t-test was calculated in the software Statistica ${ }^{\text {TM }} 7.0$ and the Varpart in the software R (R DEVELOPMENT CORE TEAM, 2012) with the Vegan package (Oksanen et al., 2015). The level of significance used in all analyses was $\mathrm{p}<0.05$.

\section{Results}

\subsection{Ichthyofauna survey}

We caught 5,964 fishes of 82 species, 21 families, and five orders (Appendix A). The orders Characiformes (38 species) and Siluriformes (34 species) comprised 88\% of all species collected. In addition, we collected specimens of the orders Gymnotiformes (six species), Perciformes (three species), and Myliobatiformes (one specie).

The species with highest abundance in number (CPUE) upstream of the Branca Waterfall were Leporinus friderici, Astyanax altiparanae, Astyanax aff. fasciatus, and Leporinus obtusidens. The most abundant species downstream of the Branca Waterfall were Schizodon borellii, L. friderici, A. altiparanae, and L. obtusidens. In addition, this biotope also showed the largest number of long-distance migratory species (13). Among the migratory species, the most abundant and frequent was L. obtusidens, captured in the three downstream sites (Appendix A). Five fish species recorded 
(Myloplus tiete, Brycon orbignyanus, Pseudoplatystoma corruscans, Salminus hilarii, and Salminus brasiliensis) are on the list of endangered or vulnerable species (IUCN, 2014). In the present study these species showed expressive frequencies in both biotopes.

\subsection{Assemblage attributes}

Total abundance (CPUE) differed significantly between biotopes, both in number $(\mathrm{t}=-2.56 ; \mathrm{p}=0.01)$ and biomass $(\mathrm{t}=-6.06 ; \mathrm{p}<0.01)$ (Figure $2 \mathrm{a}$ and $\mathrm{b}$, respectively). Higher mean values of CPUE, in number and weight, were registered downstream of Branca Waterfall (216.73 individuals and $78.00 \mathrm{~kg} .1000 \mathrm{~m}^{-2}$ of nets in $24 \mathrm{~h}$, respectively). We recorded the highest species richness downstream of the Branca Waterfall (70 species). Among those, 32 species were exclusive of this site (Appendix A), including some large-bodied (see Vazzoler, 1996) Siluriformes: Auchenipterus osteomystax, Hemisorubim platyrhynchos, Megalonema platanum, Pterodoras granulosus, Pimelodus ornatus and Sorubim lima. Upstream of the Branca Waterfall, we recorded 50 species, including 12 exclusive species (Appendix A). We observed significant differences in species richness $(\mathrm{t}=-3.61 ; \mathrm{p}<0.01)$ and evenness $(\mathrm{t}=2.06 ; \mathrm{p}<0.05$; Figure $2 \mathrm{c}$ and $\mathrm{d}$, respectively).

\subsection{Fish assemblage distribution patterns}

The NMDS showed that the composition and structure of the fish assemblage segregated between biotopes. In this analysis, we reached a final stress of 0.23 (Monte Carlo test; $\mathrm{p}<0.01$ ) for a two dimensional solution. The spatial variability was evidenced by the axis 1 , showing that the composition and structure of the fish assemblage are strongly influenced by changes along the longitudinal gradient (Figure 3).

As pointed out by the IndVal, the two biotopes were characterized by different sets of indicator species. We identified fourteen species as indicators downstream of the Branca Waterfall, including mainly large migratory species (five; as mentioned by Vazzoler, 1996). Four species were considered indicators upstream of the Branca Waterfall (Table 2).

Concerning environmental variables, we found significant spatial differences between biotopes, only in electrical conductivity $(\mathrm{t}=-2.10 ; \mathrm{p}<0.05)$ and turbidity
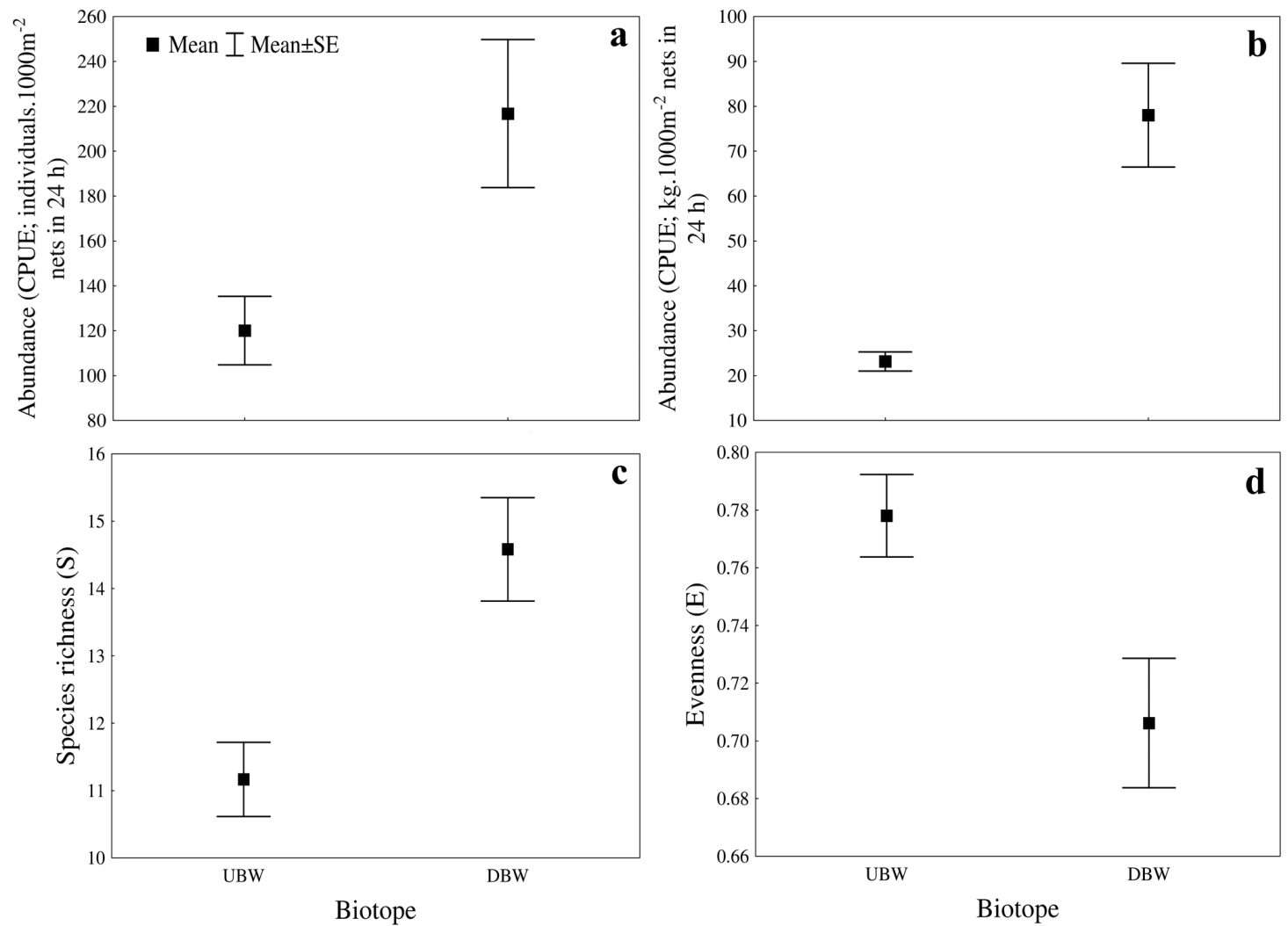

Figure 2. Results of t-test for independent samples comparing the abundance in number (a) and weight (b) of individuals (catch per unit of effort; CPUE), species richness (c) and evenness (d) between two biotopes: upstream (UBW) and downstream (DBW) of the Branca Waterfall in the Verde River, Upper Paraná River Basin, Brazil, from November 2010 to February 2012. Average values of abundance, species richness and evenness for each biotope and their standard errors are displayed in each boxes. 


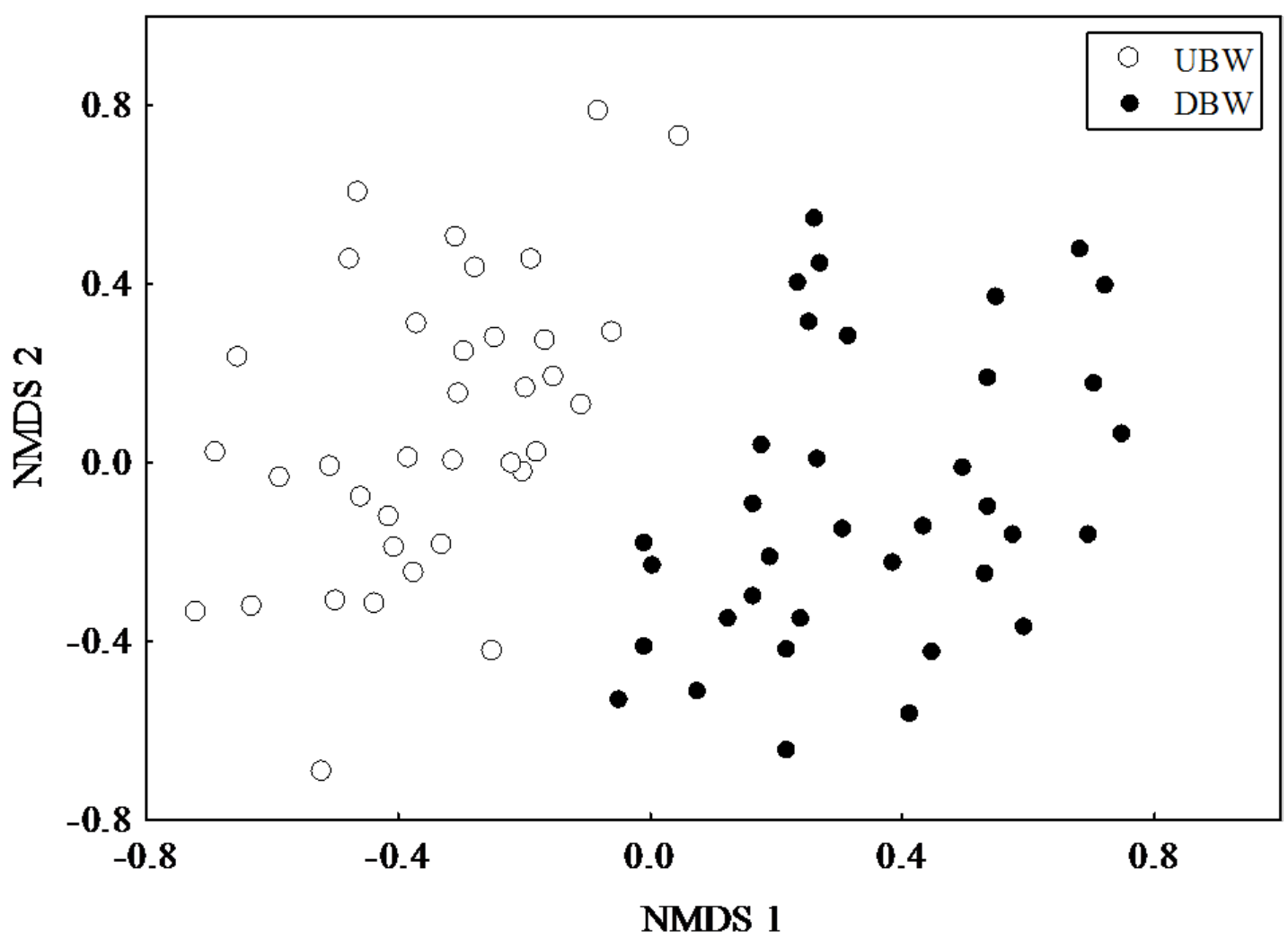

Figure 3. Scores of the axes (two dimensional solution: axis 1 and axis 2) of the nonmetric multidimensional scaling (NMDS) used for the analysis of spatial patterns, ordered by biotope: upstream (UBW) and downstream (DBW) of the Branca Waterfall, Verde River, Upper Paraná River Basin, Brazil, from November 2010 to February 2012.

Table 2. Analysis of species indicator value, showing relative abundance (RA\%), relative frequency (RF\%), and indicator value (Indval) of each species in each biotope: upstream (UBW) and downstream of the Branca Waterfall (DBW), in the Verde River, Upper Paraná River Basin, Brazil, from November 2010 to February 2012. Only the species with $p<0.05$ in the Monte Carlo test are listed.

\begin{tabular}{|c|c|c|c|c|c|}
\hline Biotope & Specie & RA\% & RF\% & IndVal & $\mathbf{p}$ \\
\hline \multirow[t]{4}{*}{ UBW } & A. aff. fasciatus & 80 & 92 & 73 & 0.00 \\
\hline & A. lacustris & 71 & 53 & 37 & 0.03 \\
\hline & E. trilineata & 86 & 39 & 33 & 0.00 \\
\hline & M. tiete & 95 & 69 & 66 & 0.00 \\
\hline \multirow[t]{14}{*}{ DBW } & A. osteomystax* & 100 & 44 & 44 & 0.00 \\
\hline & G. knerii & 98 & 83 & 81 & 0.00 \\
\hline & H. cf. cochliodon & 100 & 47 & 47 & 0.00 \\
\hline & H. orthonops & 100 & 69 & 69 & 0.00 \\
\hline & H. platyrhynchos* & 100 & 53 & 53 & 0.00 \\
\hline & M. platanum* & 100 & 17 & 17 & 0.02 \\
\hline & P. corruscans* & 94 & 25 & 24 & 0.01 \\
\hline & P. galeatus & 100 & 22 & 22 & 0.00 \\
\hline & P. gracilis & 90 & 36 & 33 & 0.00 \\
\hline & R. descalvadensis & 100 & 19 & 19 & 0.00 \\
\hline & R. vulpinus* & 100 & 39 & 39 & 0.00 \\
\hline & S. borellii & 100 & 83 & 83 & 0.00 \\
\hline & S. maculatus & 100 & 19 & 19 & 0.01 \\
\hline & S. marginatus & 100 & 22 & 22 & 0.00 \\
\hline
\end{tabular}

*Migratory species. 
$(\mathrm{t}=-2.58 ; \mathrm{p}<0.05$; Table 3$)$. We found higher mean values of electrical conductivity upstream of the Branca Waterfall. On the other hand, we recorded higher mean values of turbidity downstream of the waterfall.

Composition and structure of fish assemblages was weakly, but significantly associated with biotopes, spatial distances and environmental variables (varpart individual contributions of "a" component: adjusted $\mathrm{R}^{2}=0.06$, $\mathrm{p}<0.01$; "b" component: adjusted $\mathrm{R}^{2}=0.04, \mathrm{p}<0.01$; and "c" component: adjusted $\mathrm{R}^{2}=0.03, \mathrm{p}<0.01$, respectively).

\section{Discussion}

A small natural geographical barrier led to marked differences in the fish assemblages between biotopes. According to Robinson and Rand (2005), who studied changes in the fish assemblage along an altitudinal gradient in a southern Appalachian watershed in the U.S., fish assemblages in areas with barriers to dispersal should differ from those in areas with no barriers. In addition, local differences in abundance and richness may indicate that potential barriers limit fish dispersal (Nislow et al., 2011).

The spatial structure of the ichthyofauna pointed to marked differences between downstream and upstream stretches of the Branca Waterfall. The downstream biotope has a particular species composition, which may be explained by the influence of the natural barrier. The role of biogeographic barriers, such as waterfalls, cascades, and large rapids, in the isolation of freshwater fish is well documented (Robinson and Rand, 2005; Rahel, 2007; Júlio Júnior et al., 2009; Olden et al., 2010; Torrente-Vilara et al., 2011; Vitule et al., 2012; Dias et al., 2013), but this is not the case for small natural barriers. Barriers constitute a determining factor in the composition of regional faunas and ichthyofauna dissimilarity. The Branca Waterfall causes a disruption in the longitudinal gradient of the river. It possibly acts as an ecological filter that limits the ascendant and descendant movement of fish between the sites located upstream and downstream of the waterfall.

The absence of migratory species upstream of barriers is attributed to geographic isolation, as barriers impede the dispersal needed to complete the life cycle of fish (Britto and Sirol, 2005). In the present study, the small natural barrier has apparently isolated not only the small-sized species with low dispersal capacity, but also large migratory Siluriformes (as mentioned in Vazzoler, 1996), which were considered indicator species downstream of the Branca Waterfall. However, records of species in the upper stretches also suggest bidirectional movements, as some long-distance migratory species were recorded in both biotopes. Most of these species belong to the order Characiformes, such as L. elongatus, S. brasiliensis, and S. hilarii. Our data suggest that these species transpose the Branca Waterfall and possibly use upstream areas for their reproductive activities. In order to migrate upstream of a river, a fish should swim faster than the water velocity, which requires a large amount of energy. As Characiformes are thought to be more efficient swimmers than the Siluriformes
Table 3. Environmental variables (mean \pm standard deviation) for the two biotopes: upstream (UBW) and downstream of the Branca Waterfall (DBW), in the Verde River, Upper Paraná River Basin, Brazil, from November 2010 to February 2012.

\begin{tabular}{lcc}
\hline $\begin{array}{c}\text { Environmental } \\
\text { variable/Biotope }\end{array}$ & UBW & DBW \\
\hline $\begin{array}{l}\text { Water temperature } \\
\left({ }^{\circ} \mathrm{C}\right)\end{array}$ & $26.20 \pm 2.08$ & $26.6 \pm 1.84$ \\
\hline $\begin{array}{l}\text { Dissolved oxygen } \\
(\mathrm{mg} / \mathrm{l})\end{array}$ & $7.81 \pm 0.73$ & $7.69 \pm 0.68$ \\
\hline $\mathrm{pH}$ & $6.50 \pm 1.25$ & $6.80 \pm 0.52$ \\
\hline $\begin{array}{l}\text { Electrical } \\
\text { conductivity } \\
(\mu \mathrm{S} / \mathrm{cm})\end{array}$ & $26.47 \pm 12.36$ & $22.41 \pm 13.56$ \\
\hline Turbidity (NTU) & $21.09 \pm 13.29$ & $33.42 \pm 35.55$ \\
\hline $\begin{array}{l}\text { Water transparency } \\
(\mathrm{cm})\end{array}$ & $70.55 \pm 40.52$ & $79.70 \pm 41.04$ \\
\hline
\end{tabular}

(Santos et al., 2007; Makrakis et al., 2010), they would have better capacity to transpose barriers. These results indicate that the Branca Waterfall is not a completely unbridgeable barrier (a small barrier), especially in periods of flood. However, the Verde River's barrier plays a selective role in the passage of fish upstream.

As previously reported, Verde River has its mouth in the reservoir of Porto Primavera. According to Agostinho et al. $(2007,2008)$, there is a high reduction in diversity and productivity in reservoirs, which compels species to search for alternative sites for survival and reproduction. Therefore, the Verde River is an important alternative route for migratory species. The importance of the maintenance of free stretches in tributaries upstream reservoirs it is well documented in the literature (Hoffmann et al., 2005; Agostinho et al., 2008; Gubiani et al., 2010). In addition, according to Olden et al. (2010), biogeographic processes that increase habitat isolation and limit dispersal resulted in high diversity of freshwater fish. Hence, the high diversity, mainly of migratory species, observed downstream of the Branca Waterfall suggests that the ichthyofauna is under the influence of both the Porto Primavera reservoir and the waterfall itself, and is highly isolated and diverse.

Physical and chemical factors are pointed as important for determining the distribution and composition of fish assemblages (Matthews, 1998; Jackson et al., 2001; Oberdorff et al., 2001; Barros et al., 2013). However, in the present study we observed a weak correlation between selected environmental variables and geographical distance with the spatial structure of the ichthyofauna. In addition to the abiotic factors and geographical distance, several other factors may influence the structuring of fish assemblages, such as biotic factors (e.g. predation and competition), regional factors (e.g. climatic variables) (Jackson et al., 2001). It is clear, though, that dispersal barriers, such as the small barrier of Branca Waterfall, played an important role promoting spatial variations in fish assemblages. 
Therefore, small barriers should be assessed in detail not only in the Verde River, but also in other rivers.

There is no consensus on the waterfall height that would constitute a threshold to prevent freshwater fish from dispersing upstream (i.e., an insurmountable barrier, sensu Dias et al., 2013). However, our study showed that small barriers may be crucial in structuring fish assemblages. The Branca Waterfall has a strong influence on the spatial distribution of the fish fauna of the Verde River. It plays a key role in the segregation of assemblages, and provides the stretch downstream of Branca Waterfall with a rich and diverse fauna. In conclusion, conservation and management strategies of aquatic organisms should consider that even small barriers may cause differences in community structure or even isolate communities (Rahel, 2007; Júlio Júnior et al., 2009; Torrente-Vilara et al., 2011; and results reported herein).

\section{Acknowledgements}

We thank the Research Group on Fishing Resources and Limnology (GERPEL) for the help in fieldwork. Eletrosul - Centrais Elétricas SA funded our research. Capes granted us a research fellowship. E. A. Gubiani received a scientific productivity fellowship from the Brazilian Research Council (CNPq; process 302143/2011-4) and acknowledges this agency for the grants received.

\section{References}

ABELL, R., THIEME, M.L., REVENGA, C., BRYER, M., KOTTELAT, M., BOGUTSKAYA, N., COAD, B., MANDRAK, N., BALDERAS, S.C., BUSSING, W., STIASSNY, M.L.J., SKELTON, P., ALLEN, G.R., UNMACK, P., NASEKA, A., NG, R., SINDORF, N., ROBERTSON, J., ARMIJO, E., HIGGINS, J.V., HEIBEL, T.J., WIKRAMANAYAKE, E., OLSON, D., LÓPEZ, H.L., REIS, R.E., LUNDBERG, J.G., SABAJ PÉREZ, M.H. and PETRY, P., 2008. Freshwater ecoregions of the World: a new map of biogeographic units for freshwater biodiversity conservation. Bioscience, vol. 58, no. 5, pp. 403-414. http:// dx.doi.org/10.1641/B580507.

AGOSTINHO, A.A., GOMES, L.C. and PELICICE, F.M., 2007. Ecologia e manejo de recursos pesqueiros em reservatórios do Brasil. Maringá: EDUEM. 501 p.

AGOSTINHO, A.A., PELICICE, F.M. and GOMES, L.C., 2008. Dams and the fish fauna of the Neotropical region: impacts and management related to diversity and fisheries. Brazilian Journal of Biology $=$ Revista Brasileira de Biologia, vol. 68, no. 4, suppl., pp. 1119-1132. http://dx.doi.org/10.1590/S151969842008000500019. PMid:19197482.

ALEXANDRE, C.M. and ALMEIDA, P.R., 2010. The impact of small physical obstacles on the structure of freshwater fish assemblages. River Research and Applications, vol. 26, pp. 977-994.

AMERICAN VETERINARY MEDICAL ASSOCIATION AVMA, 2001. Report of the AVMA panel on euthanasia. Journal of the American Veterinary Medical Association, vol. 218, no. 5, pp. 669-696. http://dx.doi.org/10.2460/javma.2001.218.669. PMid:11280396.
ANGERMEIER, P.L. and WINSTON, M.R., 1998. Local vs. regional influences on local diversity in stream fish communities of Virginia. Ecology, vol. 79, no. 3, pp. 911-927. http://dx.doi. org/10.1890/0012-9658(1998)079[0911:LVRIOL]2.0.CO;2.

BALON, E.K. and STEWART, D.J., 1983. Fish assemblages in a river with unusual gradient (Luongo, Africa - Zaire system), reflections on river zonation, and description of another new species. Environmental Biology of Fishes, vol. 9, no. 3-4, pp. 225-252. http://dx.doi.org/10.1007/BF00692373.

BARROS, D.F., ALBERNAZ, A.L.M., ZUANON, J., ESPÍRITO SANTO, H.M.V., MENDONÇA, F.P. and GALUCH, A.V., 2013. Effects of isolation and environmental variables on fish community structure in the Brazilian Amazon Madeira-Purus interfluve. Brazilian Journal of Biology $=$ Revista Brasileira de Biologia, vol. 73, no. 3, pp. 491-499. http://dx.doi.org/10.1590/ S1519-69842013000300005. PMid:24212688.

BRITTO, S.G.C. and SIROL, R.N., 2005. Transposição de peixes como forma de manejo: as escadas do Complexo Canoas, médio Paranapanema, bacia do Alto Paraná. In: M.G. NOGUEIRA, R. HENRY and A. JORCIN, eds. Ecologia de reservatórios: impactos potenciais, ações de manejo e sistemas em cascata. São Carlos: Rima, pp. 285-304.

COTE, D., KEHLER, D.G., BOURNE, C. and WIERSMA, Y.F., 2009. A new measure of longitudinal connectivity for stream networks. Landscape Ecology, vol. 24, no. 1, pp. 101-113. http:// dx.doi.org/10.1007/s10980-008-9283-y.

DIAS, M.S., CORNU, J.F., OBERDORFF, T., LASSO, C.A. and TEDESCO, P.A., 2013. Natural fragmentation in river networks as a driver of speciation for freshwater fishes. Ecography, vol. 35 , pp. 1-7.

DUFRÊNE, M. and LEGENDRE, P., 1997. Species assemblages and indicator species: the need for a flexible asymmetrical approach. Ecological Monographs, vol. 67, pp. 345-366.

FELIPE, T.R. and SÚAREZ, Y.R., 2010. Caracterização e influência dos fatores ambientais nas assembleias de peixes de riachos em duas microbacias urbanas, alto rio Paraná. Biota Neotropica, vol. 10, no. 2, pp. 143-151. http://dx.doi.org/10.1590/ S1676-06032010000200018.

GRAÇA, W.J. and PAVANELLI, C.S., 2007. Peixes da planície de inundação do alto rio Paraná e áreas adjacentes. Maringá: EDUEM. $241 \mathrm{p}$.

GUBIANI, É.A., GOMES, L.C., AGOSTINHO, A.A. and BAUMGARTNER, G., 2010. Variations in fish assemblages in a tributary of the Upper Paraná River, Brazil: a comparison between pre and post-closure phases of dams. River Research and Applications, vol. 26, no. 7, pp. 848-865. http://dx.doi. org/10.1002/rra.1298.

HOEINGHAUS, D.J., WINEMILLER, K.O. and BIRNBAUM, J.S., 2007. Local and regional determinants of stream fish assemblage structure: inferences based on taxonomic vs. functional groups. Journal of Biogeography, vol. 34, no. 2, pp. 324-338. http:// dx.doi.org/10.1111/j.1365-2699.2006.01587.x.

HOFFMANN, A.C., ORSI, M.L. and SHIBATTA, O.A., 2005. Diversidade de peixes do reservatório da UHE Escola Engenharia Mackenzie (Capivara), Rio Paranapanema, bacia do alto rio Paraná, Brasil, e a importância dos grandes tributários na sua manutenção. Iheringia. Serie Zoologia, vol. 95, pp. 319-325. 
HUGUENY, B., OBERDORFF, T. and TEDESCO, P.A., 2010. Community ecology of river fishes: a large-scale perspective. American Fisheries Society Symposium, vol. 73, pp. 1-34.

INTERNATIONAL UNION FOR CONSERVATION OF NATURE - IUCN, 2014 [viewed 15 May 2014]. IUCN Red List of Threatened Species. Version 2014.1 [online]. Available from: http://www.iucnredlist.org

JACKSON, D.A. and HARVEY, H.H., 1989. Biogeographic associations in fish assemblages: local vs. regional processes. Ecology, vol. 70, no. 5, pp. 1472-1485. http://dx.doi.org/10.2307/1938206.

JACKSON, D.A., PERES-NETO, P.R. and OLDEN, J.D., 2001. What controls who is where in freshwater fish communities - the roles of biotic, abiotic, and spatial factors. Canadian Journal of Fisheries and Aquatic Sciences, vol. 58, pp. 157-170.

JÚLIO JÚNIOR, H.F., TÓS, C.D., AGOSTINHO, Â.A. and PAVANELLI, C.S. 2009. A massive invasion of fish species after eliminating a natural barrier in the upper rio Paraná basin. Neotropical Ichthyology, vol. 7, no. 4, pp. 709-718. http://dx.doi. org/10.1590/S1679-62252009000400021.

KING, M., 1995. Fisheries biology, assessment and management. Oxford: Fishing News Books. 341 p.

KLINK, C.A. and MACHADO, R.B., 2005. A conservação do Cerrado brasileiro. Megadiversidade, vol. 1, no. 1, pp. 147-155.

KRUSKAL, J.B., 1964. Nonmetric multidimensional scaling: a numerical method. Psychometrika, vol. 29, no. 2, pp. 115-129. http://dx.doi.org/10.1007/BF02289694.

LEGENDRE, P. and GALLAGHER, E.D., 2001. Ecologically meaningful transformations for ordination of species data. Oecologia, vol. 129, no. 2, pp. 271-280. http://dx.doi.org/10.1007/ s004420100716.

MAGURRAN, A.E., 1988. Ecological diversity and its measurement. London: Croom Helm. 192 p.

MAKRAKIS, S., MIRANDA, L.E., GOMES, L.C., MAKRAKIS, M.C. and JUNIOR, H.M.F., 2010. Ascent of Neotropical migratory fish in the Itaipu reservoir fish pass. River Research and Applications, vol. 1, pp. 5-18.

MATTHEWS, W.J., 1998. Patterns in freshwater fish ecology. New York: Chapman \& Hall. 756 p.

MCCUNE, B. and GRACE, J.B., 2002. Analysis of ecological communities. Oregon: Gleneden Beach. 300 p.

MCCUNE, B. and MEFFORD, M.J., 2006. PC-ORD, version 5.0, multivariate analysis of ecological data. Gleneden Beach: MjM Solfware Desing. 40 p.

MEADOR, M.R. and GOLDSTEIN, R.M., 2003. Assessing water quality at large geographic scales: relations among land use, water physicochemistry, riparian condition, and fish community structure. Environmental Management, vol. 31, no. 4, pp. 504-517. http://dx.doi.org/10.1007/s00267-002-2805-5. PMid:12677296.

MIRANDA, L.E. and RABORN, S.W., 2000. From zonation to connectivity: fluvial ecology paradigms of the $20^{\text {th }}$ century. Polskie Archiwum Hydrobiologii, vol. 47, no. 1, pp. 5-19.

NEKOLA, J.C. and WHITE, P.S., 1999. The distance decay of similarity in biogeography and ecology. Journal of Biogeography, vol. 26, no. 4, pp. 867-878. http://dx.doi.org/10.1046/j.13652699.1999.00305.x.
NISLOW, K.H., HUDY, M., LETCHER, B.H. and SMITH, E.P., 2011. Variation in local abundance and species richness of stream fishes in relation to dispersal barriers: implications for management and conservation. Freshwater Biology, vol. 56, no. 10, pp. 2135 2144. http://dx.doi.org/10.1111/j.1365-2427.2011.02634.x.

OBERDORFF, T., PONT, D., HUGUENY, B. and CHESSEL, D., 2001. A probabilistic model characterizing fish assemblages of French rivers: a framework for environmental assessment. Freshwater Biology, vol. 46, no. 3, pp. 399-415. http://dx.doi. org/10.1046/j.1365-2427.2001.00669.x.

OKSANEN, J., BLANCHET, F.G., KINDT, R., LEGENDRE, P., MINCHIN, P.R., O'HARA, R.B., SIMPSON, G.L., SOLYMOS, P., HENRY, M., STEVENS, H. and WAGNER, H., 2015 [viewed 16 January 2015]. Vegan: Community Ecology Package version 2.2-1 [online]. Available from: http://CRAN.R-project.org/ package $=$ vegan

OLDEN, J.D., JACKSON, D.A. and PERES-NETO, P.R., 2001. Spatial isolation and fish communities in drainage lakes. Oecologia, vol. 127, no. 4, pp. 572-585. http://dx.doi.org/10.1007/ s004420000620.

OLDEN, J.D., KENNARD, M.J., LEPRIEUR, F., TEDESCO, P.A., WINEMILLER, K.O. and GARCÍA-BERTHOU, E., 2010. Conservation biogeography of freshwater fishes: recent progress and future challenges. Diversity \& Distributions, vol. 16, no. 3, pp. 496-513. http://dx.doi.org/10.1111/j.1472-4642.2010.00655.x.

PERES-NETO, P., LEGENDRE, P., DRAY, S. and BORCARD, D., 2006. Variation partitioning of species data matrices: estimation and comparison of fractions. Ecology, vol. 87, no. 10, pp. 26142625. http://dx.doi.org/10.1890/0012-9658(2006)87[2614:VPO SDM]2.0.CO;2. PMid:17089669.

PETRY, A.C., AGOSTINHO, A.A. and GOMES, L.C., 2003. Fish assemblages of tropical floodplain lagoons: exploring the role of connectivity in a dry year. Neotropical Ichthyology, vol. 1, no. 2, pp. 111-119. http://dx.doi.org/10.1590/S1679-62252003000200005.

POFF, N.L., 1997. Landscape filters and species traits: towards mechanistic understanding and prediction in stream ecology. Journal of the North American Benthological Society, vol. 16, no. 2, pp. 391-409. http://dx.doi.org/10.2307/1468026.

QUIST, M.C., RAHEL, F.J. and HUBERT, W.A., 2005. Hierarchical faunal filters: an approach to assessing effects of habitat and nonnative species on native fishes. Ecology Freshwater Fish, vol. 14, no. 1, pp. 24-39. http://dx.doi.org/10.1111/j.1600-0633.2004.00073.x.

R DEVELOPMENT CORE TEAM., 2012 [viewed 26 October 2012]. R: a language and environment for statistical computing [online]. Vienna: R Foundation for Statistical Computing. Available from: http://www.R-project.org

RAHEL, F.J. and HUBERT, W.A., 1991. Fish assemblages and habitat gradients in a rocky Mountain-Great plains stream: biotic zonation and additive patterns of community Change. Transactions of the American Fisheries Society, vol. 120, no. 3, pp. 319-332. http://dx.doi.org/10.1577/1548-8659(1991)120<0319:FAAHG $\mathrm{I}>2.3 . \mathrm{CO} ; 2$.

RAHEL, F.J., 2007. Biogeographic barriers, connectivity and homogenization of freshwater faunas: it's a small world after all. Freshwater Biology, vol. 52, no. 4, pp. 696-710. http://dx.doi. org/10.1111/j.1365-2427.2006.01708.x.

ROBINSON, J.L. and RAND, P.S., 2005. Discontinuity in fish assemblages across an elevation gradient in a southern Appalachian 
watershed, USA. Ecology Freshwater Fish, vol. 14, no. 1, pp. 14-23. http://dx.doi.org/10.1111/j.1600-0633.2005.00063.x.

SANTOS, H.A., POMPEU, P.S. and MARTINEZ, C.B., 2007. Swimming performance of the migratory Neotropical fish Leporinus reinhardti (Characiformes: Anostomidae). Neotropical Ichthyology, vol. 5, no. 2, pp. 139-146. http://dx.doi.org/10.1590/ S1679-62252007000200007.

STANFORD, J.A. and WARD, J.V., 2001. Revisiting the serial discontinuity concept. Regulated Rivers: Research and Management, vol. 17, no. 4-5, pp. 303-310. http://dx.doi.org/10.1002/rrr.659.

SÚAREZ, Y.R. and PETRERE JUNIOR, M., 2007. Environmental factors predicting fish community structure in two neotropical rivers in Brazil. Neotropical Ichthyology, vol. 5, no. 1, pp. 61-68. http://dx.doi.org/10.1590/S1679-62252007000100008.

TEIXEIRA, T.P., PINTO, B.C.T., TERRA, B.F., ESTILIANO, E.O., GRACIA, D. and ARAÚJO, F.G., 2005. Diversidade das assembleias de peixes nas quatro unidades geográficas do rio Paraíba do Sul. Iheringia: Série Zoologia, vol. 95, no. 4, pp. 347-357.

TOBLER, W.R., 1970. A computer movie simulating urban growth in the Detroit Region. Economic Geography, vol. 46, pp. 234-240. http://dx.doi.org/10.2307/143141.
TORRENTE-VILARA, G., ZUANON, J., LEPRIEUR, F., OBERDORFF, T. and TEDESCO, P.A., 2011. Effects of natural rapids and waterfalls on fish assemblage structure in the Madeira River (Amazon Basin). Ecology Freshwater Fish, vol. 20, no. 4, pp. 588-597. http://dx.doi.org/10.1111/j.1600-0633.2011.00508.x.

UIEDA, V.S. and PINTO, T.L.F., 2011. Feeding selectivity of ichthyofauna in a tropical stream: space-time variations in trophic plasticity. Community Ecology, vol. 12, no. 1, pp. 31-39. http:// dx.doi.org/10.1556/ComEc.12.2011.1.5.

VAZZOLER, A.E.A.M., 1996. Biologia da reprodução de peixes teleósteos: teoria e prática. Maringá: EDUEM. 169 p.

VITULE, J.R.S., SKÓRA, F. and ABILHOA, V., 2012. Homogenization of freshwater fish faunas after the elimination of a natural barrier by a dam in Neotropics. Diversity \& Distributions, vol. 18, no. 2, pp. 111-120. http://dx.doi.org/10.1111/j.1472-4642.2011.00821.x.

WARD, J.V. and STANFORD, J.A., 1983. The serial discontinuity concept of lotic ecosystems. In: T. FONTAINE and S.M. BARTELL, eds. Dynamics of lotic ecosystems. Ann Arbor: Ann Arbor Scientific Publishers, pp. 29-42. 
Appendix A. Taxonomic nomenclature following Reis et al. (2003) and Graça and Pavanelli (2007) and abundance in number (CPUE) for the species collected in each biotope: upstream (UBW) and downstream of the Branca Waterfall (DBW), in the Verde River, Upper Paraná River Basin, Brazil, from November 2010 to February 2012.

\begin{tabular}{|c|c|c|c|}
\hline & \multirow[t]{2}{*}{$\begin{array}{c}\text { Voucher } \\
\text { NUP }\end{array}$} & \multicolumn{2}{|c|}{$\begin{array}{c}\text { Abundance - number of } \\
\text { individuals (CPUE) } \\
\text { by Biotope }\end{array}$} \\
\hline & & UBW & DBW \\
\hline \multicolumn{4}{|l|}{ Class Chondrichthyes } \\
\hline \multicolumn{4}{|l|}{ ORDER MYLIOBATIFORMES } \\
\hline \multicolumn{4}{|l|}{ Family Potamotrygonidae } \\
\hline Potamotrygon cf. falkneri Castex \& Maciel, 1963 & 10918 & & $0.05^{*}$ \\
\hline \multicolumn{4}{|l|}{ Class Osteichthyes } \\
\hline \multicolumn{4}{|l|}{ ORDER CHARACIFORMES } \\
\hline \multicolumn{4}{|l|}{ Family Paradontidae } \\
\hline Apareiodon affinis (Steindachner, 1879) & 14457 & 0.11 & 0.16 \\
\hline Parodon nasus Kner, 1859 & 6194 & 0.85 & 0.53 \\
\hline \multicolumn{4}{|l|}{ Family Curimatidae } \\
\hline Steindachnerina insculpta (Fernández-Yápez, 1948) & 1424 & & $0.11 *$ \\
\hline Steindachnerina brevipinna (Eigenmann \& Eigenmann, 1889) & 2372 & & $0.05^{*}$ \\
\hline \multicolumn{4}{|l|}{ Family Prochilodontidae } \\
\hline Prochilodus lineatus (Valenciennes, 1836) & 6151 & 1.06 & 2.07 \\
\hline \multicolumn{4}{|l|}{ Family Anostomidae } \\
\hline Leporinus sp. & & $0.05 *$ & \\
\hline Leporellus vittatus (Valenciennes, 1850) & 1902 & 1.06 & 0.64 \\
\hline Leporinus amblyrhynchus Garavello \& Britski, 1987 & 14468 & $0.21 *$ & \\
\hline Leporinus obtusidens (Valenciennes, 1836) & 277 & 10.7 & 15.2 \\
\hline Leporinus friderici (Bloch, 1794) & 1180 & 27.59 & 41.36 \\
\hline Leporinus lacustris Campos, 1945 & 3308 & $0.11 *$ & \\
\hline Leporinus piavussu Britski, Birindelli \& Garavello, 2012 & 14070 & 0.11 & 0.37 \\
\hline Leporinus octofasciatus Steindachner, 1915 & 11867 & 1.22 & 0.37 \\
\hline Leporinus striatus Kner, 1858 & 3810 & & $0.16^{*}$ \\
\hline Schizodon altoparanae Garavello \& Britski, 1990 & 2020 & & $0.48^{*}$ \\
\hline Schizodon borellii (Boulenger, 1900) & 1925 & 0.05 & 78.54 \\
\hline Schizodon nasutus Kner, 1858 & 2495 & & $0.21 *$ \\
\hline \multicolumn{4}{|l|}{ Family Characidae } \\
\hline Astyanax aff. fasciatus (Cuvier, 1819) & 32 & 17 & 4.34 \\
\hline Astyanax aff. paranae Eigenmann, 1914 & 133 & $0.37 *$ & \\
\hline Astyanax altiparanae Garutti \& Britski, 2000 & 6149 & 20.87 & 16.21 \\
\hline Moenkhausia aff. intermedia Eigenmann, 1908 & 3208 & & $0.11 *$ \\
\hline Moenkhausia aff. sanctaefilomenae (Steindachner, 1907) & 371 & 0.58 & 0.05 \\
\hline Piabina argentea Reinhardt, 1867 & 6209 & $0.05 *$ & \\
\hline \multicolumn{4}{|l|}{ Subfamily Salmininae } \\
\hline Salminus brasiliensis (Cuvier, 1816) & 1865 & 3.23 & 1.85 \\
\hline Salminus hilarii Valenciennes, 1850 & 1893 & 0.69 & 0.26 \\
\hline \multicolumn{4}{|l|}{ Subfamily Bryconinae } \\
\hline Brycon orbignyanus (Valenciennes, 1850) & 12174 & 0.32 & 0.37 \\
\hline \multicolumn{4}{|l|}{ Subfamily Serrasalminae } \\
\hline Myloplus tiete (Eigenmann \& Norris, 1900) & 2484 & 2.81 & 0.16 \\
\hline Serrasalmus maculatus Kner, 1858 & 396 & & $0.42 *$ \\
\hline Serrasalmus marginatus Valenciennes, 1837 & 439 & & $0.42 *$ \\
\hline \multicolumn{4}{|l|}{ Subfamily Characinae } \\
\hline Galeocharax knerii (Steindachner, 1879) & 263 & 0.16 & 6.94 \\
\hline Roeboides descalvadensis Fowler, 1932 & 13601 & & $0.53 *$ \\
\hline
\end{tabular}

*Species exclusive of each biotope. 
Appendix A. Continued...

\begin{tabular}{|c|c|c|c|}
\hline & \multirow[t]{2}{*}{$\begin{array}{l}\text { Voucher } \\
\text { NUP }\end{array}$} & \multicolumn{2}{|c|}{$\begin{array}{c}\text { Abundance - number of } \\
\text { individuals (CPUE) } \\
\text { by Biotope }\end{array}$} \\
\hline & & UBW & DBW \\
\hline \multicolumn{4}{|l|}{ Family Acestrorhynchidae } \\
\hline Acestrorhynchus lacustris (Lütken, 1875) & 14483 & 3.18 & 1.32 \\
\hline \multicolumn{4}{|l|}{ Family Cynodontidae } \\
\hline Rhaphiodon vulpinus Spix \& Agassiz, 1829 & 11153 & & $1.17 *$ \\
\hline \multicolumn{4}{|l|}{ Family Erythrinidae } \\
\hline Erythrinus Erythrinus (Bloch \& Schneider, 1801) & 11197 & $0.11 *$ & \\
\hline Hoplias sp. 1 & 292 & 2.38 & 1.54 \\
\hline Hoplias sp. 2 & 3457 & 0.53 & 0.21 \\
\hline Hoplias sp. 3 & 3458 & $0.16^{*}$ & \\
\hline \multicolumn{4}{|l|}{ Family Hemiodontidae } \\
\hline Hemiodus orthonops Eigenmann \& Kennedy, 1903 & 10609 & & $12.18^{*}$ \\
\hline \multicolumn{4}{|l|}{ ORDER SILURIFORMES } \\
\hline \multicolumn{4}{|l|}{ Family Callichthyidae } \\
\hline Callichthys callichthys (Linnaeus, 1758) & 1722 & $0.05^{*}$ & \\
\hline \multicolumn{4}{|l|}{ Family Cetopsidae } \\
\hline Cetopsis gobioides Kner, 1858 & 2476 & & $0.11^{*}$ \\
\hline \multicolumn{4}{|l|}{ Family Loricariidae } \\
\hline \multicolumn{4}{|l|}{ Subfamily Ancistrinae } \\
\hline Megalancistrus parananus (Peters, 1881) & 9111 & & $0.05^{*}$ \\
\hline \multicolumn{4}{|l|}{ Subfamily Loricariinae } \\
\hline Loricariichthys platymetopon Isbrücker \& Nijssen, 1979 & 13632 & & $0.26^{*}$ \\
\hline Loricariichthys rostratus Reis \& Pereira, 2000 & 4730 & & $0.11 *$ \\
\hline Rineloricaria latirostris (Boulenger, 1900) & 13669 & 0.11 & 0.05 \\
\hline Rineloricaria sp. & & 0.05 & 0.05 \\
\hline \multicolumn{4}{|l|}{ Subfamily Hypostominae } \\
\hline Hypostomus ancistroides (Ihering, 1911) & 332 & $0.05^{*}$ & \\
\hline Hypostomus cf. cochliodon Kner, 1854 & 2556 & & $2.86^{*}$ \\
\hline Hypostomus margaritifer (Regan, 1908) & 1766 & $0.05^{*}$ & \\
\hline Hypostomus microstomus Weber, 1987 & 1725 & 0.53 & 0.05 \\
\hline Hypostomus cf. nigromaculatus (Schubart, 1967) & 12462 & 0.58 & 0.05 \\
\hline Hypostomus cf. regani (Ihering, 1905) & 2286 & 1.85 & 0.37 \\
\hline Hypostomus cf. strigaticeps (Regan, 1908) & 3190 & 2.54 & 0.95 \\
\hline Pterygoplichthys anisitsi Eigenmann \& Kennedy, 1903 & 1529 & & $0.16^{*}$ \\
\hline \multicolumn{4}{|l|}{ Family Heptapteridae } \\
\hline Pimelodella avanhandavae Eigenmann, 1917 & 3455 & & $0.05^{*}$ \\
\hline Pimelodella gracilis (Valenciennes, 1835) & 3118 & 0.16 & 1.48 \\
\hline Pimelodella sp. & & & $0.11 *$ \\
\hline Rhamdia quelen (Quoy \& Gaimard, 1824) & 2501 & & $0.05^{*}$ \\
\hline \multicolumn{4}{|l|}{ Family Pimelodidae } \\
\hline Hemisorubim platyrhynchos (Valenciennes, 1840) & 2506 & & $3.23 *$ \\
\hline Iheringichthys labrosus (Lütken, 1874) & 671 & 0.42 & 0.64 \\
\hline Megalonema platanum (Günther, 1880) & 1729 & & $0.42 *$ \\
\hline Pimelodus cf. argenteus Perugia, 1891 & 3230 & & $0.11 *$ \\
\hline Pimelodus maculatus La Cepède, 1803 & 420 & 0.05 & 0.32 \\
\hline Pimelodus microstoma Steindachner, 1877 & 14465 & 2.44 & 1.75 \\
\hline Pimelodus ornatus Kner, 1858 & 2492 & & $0.16^{*}$ \\
\hline Pseudoplatystoma corruscans (Spix \& Agassiz, 1829 & 523 & 0.05 & 0.9 \\
\hline
\end{tabular}

*Species exclusive of each biotope. 
Appendix A. Continued...

\begin{tabular}{|c|c|c|c|}
\hline & \multirow[t]{2}{*}{$\begin{array}{l}\text { Voucher } \\
\text { NUP }\end{array}$} & \multicolumn{2}{|c|}{$\begin{array}{c}\text { Abundance - number of } \\
\text { individuals (CPUE) } \\
\text { by Biotope }\end{array}$} \\
\hline & & UBW & DBW \\
\hline Sorubim lima (Bloch \& Schneider, 1801) & 2494 & & $0.26^{*}$ \\
\hline \multicolumn{4}{|l|}{ Family Doradidae } \\
\hline Pterodoras granulosus (Valenciennes, 1821) & 4722 & & $0.21 *$ \\
\hline Rhinodoras dorbignyi (Kner, 1855) & 11151 & 0.32 & 0.11 \\
\hline Trachydoras paraguayensis (Eignmann \& Ward, 1907) & 9185 & & $0.48^{*}$ \\
\hline \multicolumn{4}{|l|}{ Family Auchenipteridae } \\
\hline Auchenipterus osteomystax (Miranda-Ribeiro, 1918) & 2627 & & $1.80^{*}$ \\
\hline Tatia neivai (Ihering, 1930) & 2080 & 0.69 & 0.05 \\
\hline Parauchenipterus galeatus (Linnaeus, 1766) & 3302 & & $1.32 *$ \\
\hline \multicolumn{4}{|l|}{ ORDER GYMNOTIFORMES } \\
\hline \multicolumn{4}{|l|}{ Family Gymnotidae } \\
\hline Gymnotus inaequilabiatus (Valenciennes, 1839) & 14327 & & $0.05^{*}$ \\
\hline Gymnotus sylvius Albert \& Fernandes-Matioli, 1999 & 13301 & 0.16 & 0.11 \\
\hline \multicolumn{4}{|l|}{ Family Sternopygidae } \\
\hline Eigenmannia trilineata López \& Castello, 1966 & 14372 & 1.59 & 0.26 \\
\hline Eigenmannia virescens (Valenciennes, 1847) & 14466 & 0.21 & 0.16 \\
\hline \multicolumn{4}{|l|}{ Family Apteronotidae } \\
\hline Sternopygus macrurus (Bloch \& Schneider, 1801) & 2096 & 0.21 & 0.16 \\
\hline Porotergus ellisi Arámburu, 1957 & 2092 & & $0.21 *$ \\
\hline \multicolumn{4}{|l|}{ ORDER PERCIFORMES } \\
\hline \multicolumn{4}{|l|}{ Family Cichlidae } \\
\hline Cichla kelberi Kullander \& Ferreira, 2006 & 1746 & 0.11 & 0.05 \\
\hline Crenicichla britskii Kullander, 1982 & 14329 & $0.11 *$ & \\
\hline Cichla piquiti Kullander \& Ferreira, 2006 & 3379 & $0.05^{*}$ & \\
\hline Species richness & & 50 & 70 \\
\hline
\end{tabular}

*Species exclusive of each biotope.

\section{References}

GRAÇA, W.J. and PAVANELLI, C.S., 2007. Peixes da planicie de inundação do alto rio Paraná e áreas adjacentes. Maringá: EDUEM. 241 p.

REIS, R.E., KULLANDER, S.O. and FERRARIS JUNIOR, C.J., 2003. Check List of the freshwater fishes of South and Central América. Porto Alegre: EDIPUCRS. 729 p. 